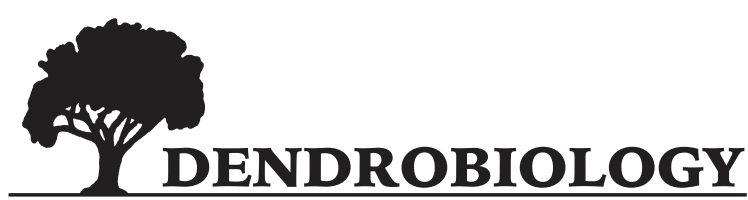

2016, vol. 76, 91-104

http://dx.doi.org/10.12657/denbio.076.009

\author{
Izabela L. Katucka, Andrzej M. Jagodziński
}

\section{Successional traits of ectomycorrhizal fungi in forest reclamation after surface mining and agricultural disturbances: A review}

\author{
Received: 9 April 2016; Accepted: 7 July 2016
}

\begin{abstract}
Ectomycorrhizal (ECM) fungi and their symbiotic associations with forest trees are among major drivers of key ecosystem functions such as carbon and nitrogen cycling, plant nutrient and water uptake from soil, plant-plant facilitation/competition and diversity regulation via common mycorrhizal networks. Through their functional traits and interactions with both abiotic and biotic environment, they also significantly affect the process of open land colonization by trees as well as vegetation succession coupled with soil and ecosystem development. Here we review the role of ECM fungi in the early primary and secondary succession following major anthropogenic disturbances. Based on the examples of mine spoils and post-agricultural lands, we demonstrate key ecosystem services provided by ECM fungi in the processes of forest restoration. We point out ecological mechanisms and adaptations which underpin ECM fungal community successional interactions, particularly life histories, dispersal, spatial structure, host preferences, and sensitivity to environmental filters. We emphasize the need of better understanding the role of ECM fungi in the forest restoration practice as it seems crucial for afforestation success and biodiversity rehabilitation. Thus, ectomycorrhizal traits should be a prime consideration in afforestation and carbon sequestration polices, sustainable forest management and biodiversity conservation practices.
\end{abstract}

Keywords: primary succession, secondary succession, mine spoils, post-agricultural lands, afforestation, ecosystem services

Addresses: I.L. Kałucka, University of Łódź, Faculty of Biology and Environmental Protection, Department of Algology and Mycology, Banacha 12/16, PL-90-237 Łódź, Poland, e-mail: ikalucka@biol. uni.lodz.pl

A.M. Jagodziński, Polish Academy of Sciences, Institute of Dendrology, Parkowa 5, PL-62-035 Kórnik, Poland; Poznań University of Life Sciences, Faculty of Forestry, Department of Game Management and Forest Protection, Wojska Polskiego 71c, PL-60-625 Poznań, Poland, e-mail: amj@man.poznan.pl

\section{Introduction}

Mycorrhizal associations are found in almost all terrestrial habitats (Read, 1991; Smith \& Read, 2008) and are the primary means by which most plants supplement their nutrient and water requirements in nature, contributing at least $10-25 \%$ of their net photosynthate carbon (C) (Simard et al., 2002; Hobbie, 
2006; Lambers et al., 2008). The extensive hyphal surface area and the small diameter of individual hyphae enable mycorrhizal fungi to radiate through the soil effectively and to take up essential compounds, especially nitrogen $(\mathrm{N})$ and phosphorus $(\mathrm{P})$ from organic residues and insoluble inorganic compounds which can be weathered by a variety of secreted enzymes (Read \& Perez-Moreno, 2003). Radiating from the rhizosphere, vegetative mycelia of mycorrhizal fungi also provide a possible interface for the neighbouring plants to form mycorrhiza and establish common mycorrhizal networks that interconnect different plant individuals (van der Heijden \& Horton, 2009; Simard et al., 2012). Moreover, they have been proved to be important drivers of the structure and dynamics of plant populations and communities (van der Heijden et al., 1998; Klironomos et al., 2011).

Mycorrhizal fungi are crucial for the ability of their plant partners to colonize novel sites, help open successional processes and develop plant communities (Dickie et al., 2013), driving primary and secondary succession that initiated by natural events (e.g., glacier retreat, volcanic eruption, wind-throw, or natural fire), or even intensive anthropogenic disturbances (e.g., mining, prescribed burning, timber harvesting, or agricultural activities). Reclamation of areas destroyed by human activities is one of the most important and urgent issues of management planning regarding a sustainable use of natural resources and efficient biodiversity conservation. Restoring destroyed landscapes and rehabilitating of natural functions, afforestation is one of the most widely applied practice (Hüttl \& Weber, 2001; FAO, 2001). Secondary forests stands are planted to counteract with anthropogenic climate change by the reduction of atmospheric $\mathrm{CO}_{2}$ and carbon sequestration (Stoate et al., 2009; van Breugel et al., 2011).

In this review, we provide a comprehensive survey about the importance of successional traits of ectomycorrhizal (ECM) communities and fungal-specific ecosystem services on the successful restoration of forests. We focussed on two types of sites representing strong, long-lasting legacies of human-induced disturbances: (i) on mining-affected areas (primary successional sites) and (ii) on post-agricultural areas (secondary successional sites).

\section{Mine spoils and post-mining disturbed sites}

Severe disturbances, such as opencast mining, including the removal of the upper soil layer, and the formation of vast areas with stripped land and various kinds of spoils and tailings usually stored in the form of spoil heaps (slag heaps, spoil banks, dumps), lead to the formation of primary successional sites.
These activities result soils with a very low initial level of macronutrients, containing no organic matter or mineralizable nitrogen, lacking water-stable micro-aggregates, having a poor water-holding capacity with a low porosity and unfavourable air-water conditions, and absorbing much solar energy causing high surface temperatures. These soils tend to get very compacted, but are frequently prone to wind and water erosion, and may show high metal(loid) concentrations, salinity and extreme $\mathrm{pH}$ values (Marx, 1975; Conesa \& Schulin, 2010).

Ideally, all these disturbed areas, if polluted, should be subjected to an extensive phytoremediation, and to restoring their original vegetation (Bradshaw \& Johnson, 1992). In general, reclamation includes also geologic protection and carbon sequestration objectives (Stanturf et al., 2014). Reclamation may either rely on natural, spontaneous successional processes (passive reclamation) or is supported by human assistance and various amelioration measures, including reinstatement of topsoil layers, fertilization, organic enrichment, seeding grasses and legumes, and tree planting (active reclamation) (Hüttl \& Weber, 2001; Macdonald et al., 2015). During an active reclamation, both the abiotic and biotic conditions of soils are being improved, which often accelerates considerably the restoration process (Macdonald et al., 2015).

In areas, where woodland vegetation dominates, restoration practices usually aim to perform afforestation (Hüttl \& Weber, 2001; Macdonald et al., 2015). However, the establishment of trees and their development on physically and chemically harsh substrates often meets difficulties. Therefore, the inoculum potential and the role of ECM fungi in facilitating tree growth in such environments have been extensively studied. The occurrence of ECM fungal propagules in strongly disturbed soils, like young mine spoils and other pure reclamation materials is usually very low (Malajczuk et al., 1994; Lunt \& Hedger, 2003; Bois et al., 2005). Fungal propagules can arrive via airborne or animal-dispersed spores or via the vegetative spread of common mycorrhizal networks from adjacent tree stands (if present) (Allen, 1991; Thiet \& Boerner, 2007). It is reported by Bois et al. (2005), that the inoculum potential of ECM fungi increases with the age of reclaimed sites and along the successional stages of the habitat and vegetation (Bois et al., 2005). Also, as suggested by Malajczuk et al. (1994), with age, a more diverse ectomycotrophic plant community can provide more niches for further ECM fungal species.

The inoculum potential, ECM root colonization, and host plant growth can be increased significantly by retaining topsoil, which was removed from the site at the beginning of mining, or transported subsequently from other places (Helm \& Carling, 1993; 
Lunt \& Hedger, 2003; Bois et al., 2005). Such types of soils are usually rich in ECM fungal propagules and hence, by placing it on the surface of the spoil, may serve as a source of symbiotic fungi for the first generation of trees. Organic enrichment of mine spoils with leaf litter was found to stimulate ECM colonization and therefore, facilitate the growth and foliar $\mathrm{N}$ concentration of tree seedlings (Lunt \& Hedger, 2003). Seedling establishment and root colonization by a diverse community of ECM fungi can also be enhanced significantly by soil subsurface preparation methods (Bauman et al., 2013).

Succession on vast abandoned and unreclaimed coal mines can be very slow. As it is reported by Russell \& La Roi (1986), the total cover of plants did not exceed $10 \%$ after 26 years, with still no ECM shrubs or trees. Formation of dense ( $>90 \%$ cover), but isolated vegetation patches that comprise the ECM host Pinus halepensis in metalloid enriched tailings may take 40 years (Parraga-Aguado et al., 2014). Spontaneous arrival of ECM pioneer trees (Salix, Populus, Betula, and Pinus spp.) onto different types of non-meliorated coal-mine wastes was observed after $10-30$ years of their establishment, and after 50 years, a relatively diverse and abundant ectomycorrhizal community were found on their roots (Pachlewski, 1956, 1958). Trees that colonize mine spoils and tailings have a significant impact on soil features and accelerate further vegetation development. They are key factors in forming fertility islands that may promote the establishment of a diverse plant community under their canopies (Parraga-Aguado et al., 2014). Therefore, besides different amelioration measures, an effective way of facilitating succession and forest restoration processes is an artificial introduction of tree seedlings on reclaimed sites (Hüttl \& Weber, 2001; Macdonald et al., 2015).

Few ECM fungi have been shown to comprise the spore bank of row, or relatively young reclamation materials, available for emerging or transplanted seedlings. The following ECM fungal taxa, proven by greenhouse bioassays, had the ability to grow on row reclamation materials: Wilcoxina sp. (E-strain), Tuber sp., Cenococcum geophilum, Laccaria sp., Thelephora americana, Suillus luteus, S. tomentosus, Rhizopogon-like, as well as Sebacinoid and Pezizales species (Danielson et al., 1983; Bois et al., 2005).

Within the first years of tree colonization on reclaimed soils, the indigenous ECM communities are usually poor consisting of a few species. ECM fungal species found on roots of seedlings and young trees up to 7 years growing on raw, or relatively young mine spoils are Wilcoxina sp., Tuber sp., Amphinema byssoides, Thelephora terrestris, Suillus-like spp. and Suillus spp. on Pinus banksiana (Danielson \& Viser, 1989; Danielson, 1991), Cenococcum geophilum on Quercus rubra and Pinus massoniana (Gebhardt et al.,
2007; Huang et al., 2012), Wilcoxina sp. and Amphinema byssoides on Picea glauca (Danielson, 1991), Laccaria laccata and Hebeloma crustuliniforme on Quercus robur (Lunt \& Hedger, 2003), Tomentella sp. and Geopora sp. on Pinus halepensis (Rincón et al., 2007) and Rhizopogon buenoi, Tomentella ellisii, Inocybe curvipes, Suillus granulatus and Atheliaceae sp. on Pinus massoniana (Huang et al., 2012). At the end of the second growing season, natural infections of Thelephora americana, Amphinema byssoides, Sebacina sp., Wilcoxina sp., Laccaria bicolor were observed on the roots of $P i$ nus banksiana and Picea glauca trees, which were outplanted on reclaimed oil sands (Onwuchekwa et al., 2014). Pisolithus tinctorius was reported as a typical early-stage ECM fungus, which is well-adapted to the low $\mathrm{pH}$ and the high temperatures of anthracite and hard coal spoils (Schramm, 1966; Marx, 1975). This species has gained a special attention because it is a common and widespread multi-host species known from many highly disturbed sites (Marx, 1977). Prior to outplanting, it has been widely used for artificial inoculation of tree seedlings, and proved perfect to increase the effectiveness of afforestation in post-mining landscapes, especially in warmer and drought-susceptible parts of the world (Marx et al., 2002).

The majority of fungal taxa listed in the above paragraph are thought to be early-stage, or early successional fungi, but some of them belong to the multi-stage group (Visser, 1995). They are known to inhabit mineral soils of a low nutrient content, or even fertilized, disturbed, or polluted urban soils with extreme $\mathrm{pH}$ values (Münzenberger et al., 2004; Bois et al., 2005; literature cited therein). Many of these taxa can survive high metal(loid) concentrations and can provide the ability for trees to colonize metalliferous substrates, or smelter waists (Staudenrausch et al., 2005; Hrynkiewicz et al., 2008; Huang et al., 2012). Metal-adapted local populations/strains of ECM fungi can significantly improve the survival rate and the performance of host trees in such sites providing a powerful tool for phytoremediation (Adriaensen et al., 2005; Jourand et al., 2010; Colpaert et al., 2011). At the level of species or higher taxa, there are not many taxa selective for, or adapted to metal-contaminated soils (Huang et al., 2014). Moreover, high metal concentrations limit the occurrence of the most ECM species (Huang et al., 2014), and species assemblages that can survive these conditions are only a subset of the species pool present in similar, but less contaminated sites (Staudenrausch et al., 2005). The occurrence of many ECM taxa may be not affected strongly by heavy metals, since local ECM populations that well-adapted to high levels of toxic metals can also be recorded. Similarly, ECM communities are determined strongly by other soil features typical among early successional conditions, 
such as the immaturity of soil, the low levels of organic matter, extreme $\mathrm{pH}$ values, and fluctuations in soil temperature and moisture (Staudenrausch et al., 2005; Huang et al., 2012). Among these adverse conditions, environmental filtering seems to be a very strong limiting factor, especially in non-meliorated sites.

Prior to outplanting, mycorrhization of seedling roots can improve the effectiveness of forest restoration overcoming the problem of the probable lack of indigenous ECM fungi on the sites. Also, inoculation by selected ECM fungi can be a key advantage for tree seedlings to surmount the initial stress of transplantation, and to acclimate to a harsh environment and adverse substrates during the first year(s) after outplanting (Grossnickle \& Reid, 1982; Reddell et al., 1999; Rincón et al., 2007). The best results are expected when fungal inocula are specifically adapted to the environmental conditions of transplantation sites (Rincón et al., 2007). However, if not intentionally mycorrhized, tree seedlings usually get colonized by native ECM fungi during their development in nurseries (Leski et al., 2010; Pietras et al., 2013). Inoculated or nursery-originated ECM species are often poor competitors among field conditions (Danielson \& Visser, 1989; Xu et al., 2001; Rincón et al., 2007), but they can help seedlings to develop new short roots susceptible to the colonization of indigenous ECM symbionts (Grossnickle, 2005), or to increase the overall percent of ECM root mycorrhization (Onwuchekwa et al., 2014). After the initial shock and drop of the mycorrhization level in the first year after transplanting, the percent ECM colonization of tree roots increases significantly. For example, two years after the plantation into a degraded gypsum soil, the level of mycorrhization of Pinus halepensis seedlings reached $60-77 \%$ by indigenous ECM fungi (Rincón et al., 2007). Similarly, indigenous ECM fungi formed mycorrhizae on 4,33 , and $72 \%$ of total short root number of Pinus banksiana outplanted on oilsands after 1,2, and 3 years, respectively (Danielson \& Viser, 1989). When seedlings are not mycorrhized artificially, the colonization rate may stay lower for a much longer time. On the roots of Quercus rubra seedlings, it reached $15 \%$ after 5 years on a lignite mine spoil (Gebhardt et al., 2007), on the roots of Pinus massoniana seedlings, reached $26 \%$ after 7 years on a $\mathrm{Pb}-\mathrm{Zn}$ mine tailing (Huang et al., 2012), and reached $3-36 \%$ on the roots of $20-30$ year-old Salix caprea individuals at a former ore mining area rich in $\mathrm{Pb}, \mathrm{Zn}, \mathrm{Cu}$ and $\mathrm{Cd}$ (Hrynkiewicz et al., 2008).

The development and functioning of ECM fungal assemblages in reclamation areas may be affected by different amelioration measures. Also, even if the colonization rate is low, the biodiversity of ECM communities can also be high due to the rapid turnover of ECM species (Staudenrausch et al., 2005), or to the high soil heterogeneity in mining sites that provide various microhabitats for different ECM fungi (Huang et al., 2014).

After the initial period of a low richness and poor diversity of ECM communities in disturbed sites, fungal communities can develop quite rapidly. In Pinus sylvestris afforestations on Mt Kamieńsk, a reclaimed lignite mine spoil heap in Poland, the number of ECM species (counted based on sporocarps) changed from one species (Geopora arenosa) to five (G. arenosa, Hebeloma mesophaeum, Inocybe dulcamara, Rhizopogon roseolus, Suillus luteus) for the third year after outplanting; and reached up to 23 species (Table 1) 14 years later, which was the time of canopy closure, the start of a detectable soil profile formation, and co-occurrence of many pioneer species known from younger stands and new, forest-dwelling species (Kałucka, unpubl.). In 20-25 years old first generation stands of Populus tremula growing in a heavy metal contaminated site, 54 ECM fungal taxa were found, many of them are selective for early successional or disturbed sites (Krpata et al., 2008). Here, the root colonization rate reached $95 \%$, and a preferential occurrence of some species in a well-developed organic horizon was recorded. The sporocarp production of ECM fungi in post-mining habitats may be rather low (Gebhardt et al., 2007). However, a massive production has been observed for some taxa (for Geopora, Hebeloma, Helvella, Inocybe, Rhizopogon, Suillus, and Tricholoma spp.), with a high total ECM sporocarp production exceeding $40 \mathrm{~kg} \mathrm{ha}^{-1} \mathrm{yr}^{-1}$ (dry weight) in a 17 years old stand (Table 1) (Kałucka, unpubl.).

Mine spoils and other soil-disturbed sites are extremely diverse and heterogeneous habitats concerning the harsh characteristics of their soils and chemical compounds, therefore they mean a great challenge for both vegetation succession and afforestation practices. Mine restoration forests differ from the forests of the same age and grow under better conditions in root biomass (Jagodziński \& Kałucka, 2010) and allocation of above-ground biomass (Jagodziński et al., 2014), which probably both affect their ECM communities. Forest stands and their fungal assemblages are exposed to strong, site-dependent environmental filtering that may be also modified by a variety of restoration and amelioration measures. Variation in successional trajectories may be very high. In such areas, the main factors affecting ECM communities are microclimatic conditions (Glen et al., 2008) and soil properties, such as the content of metalliferous contaminations (Huang et al., 2014), the maturity of soil and the presence of organic matter (Staudenrausch et al., 2005; Huang et al., 2012; 2014). A strong host effect was also observed (Huang et al., 2014). The positive effects of years elapsed since rehabilitation (stand age/tree size) are obvious. With time, ECM community richness and diversity tends to be more 
Table 1. The occurrence of ectomycorrhizal fungal sporocarps in three Scots pine plantations of different ages on Mt Kamieńsk spoil heap (Bełchatów Industrial Region, Poland)

\begin{tabular}{|c|c|c|c|}
\hline Species & AC3y & P3y & SF \\
\hline \multicolumn{4}{|l|}{ A. 3-year-old stand (Z03) } \\
\hline Geopora arenosa & 5775 & 1438.0 & 100 \\
\hline Hebeloma mesophaeum & 1 & 0.2 & 10 \\
\hline Inocybe dulcamara & 5 & 0.8 & 10 \\
\hline Rhizopogon roseolus & 3 & 2.5 & 10 \\
\hline Suillus luteus & 3 & 3.3 & 10 \\
\hline \multicolumn{4}{|c|}{ B. 14-year-old stand (Z14) } \\
\hline Chroogomphus rutilus & 131 & 43.4 & 90 \\
\hline Cortinarius sp. 1/Z14 & 7 & 1.7 & 10 \\
\hline Cortinarius sp. 2/Z14 & 4 & 0.7 & 10 \\
\hline Cortinarius decipiens & 270 & 30.2 & 40 \\
\hline Geopora arenosa & 597 & 148.7 & 70 \\
\hline Hebeloma cylindrosporum & 15 & 4.2 & 10 \\
\hline Hebeloma mesophaeum & 975 & 227.2 & 70 \\
\hline Hebeloma sp. 1/Z14 & 65 & 35.2 & 40 \\
\hline Helvella lacunosa & 8 & 8.2 & 20 \\
\hline Helvella leucomelaena* & 2468 & 7048.6 & 100 \\
\hline Hygrophorus hypothejus & 3 & 0.5 & 10 \\
\hline Inocybe dulcamara & 2158 & 349.6 & 100 \\
\hline Inocybe tjallingiorum & 8 & 1.0 & 10 \\
\hline Inocybe malenconii & 269 & 39.0 & 50 \\
\hline Laccaria proxima & 1 & 0.4 & 10 \\
\hline Rhizopogon roseolus & 505 & 428.7 & 100 \\
\hline Suillus bovinus & 1 & 0.8 & 10 \\
\hline Suillus luteus & 920 & 1023.0 & 100 \\
\hline Thelephora caryophyllea & 22 & 6.1 & 10 \\
\hline Thelephora terrestris & 12 & 4.6 & 20 \\
\hline Tricholoma albobrunneum & 15 & 14.9 & 20 \\
\hline Tricholoma scalpturatum & 302 & 93.3 & 20 \\
\hline Tricholoma terreum & 25 & 9.7 & 20 \\
\hline
\end{tabular}

similar between the older stands of spoil heaps and the surrounding forests (Gebhardt et al., 2007; Glen et al., 2008), or other mature forests (Krpata et al., 2008). However, their ECM fungal species composition is different. Specifically, the relative abundances of taxa selective for non-disturbed forests (late successional fungi, such as members of Thelephoraceae or Russulaceae) were lower (Glen et al., 2008; Huang et al., 2012), while the members of the typical early successional genera (e.g., Cenococcum, Hebeloma, Inocybe, Laccaria, Pisolithus, Scleroderma, Tomentella, Tuber, and Wilcoxina) were reported to be persistent in disturbed habitats (Glen et al., 2008; Hrynkiewicz et al., 2008; Krpata et al., 2008).

\begin{tabular}{|c|c|c|c|}
\hline Species & $\mathrm{AC} 3 \mathrm{y}$ & P3y & SF \\
\hline \multicolumn{4}{|c|}{ C. 17-year-old stand (Z17) } \\
\hline Chroogomphus rutilus & 2 & 0.7 & 10 \\
\hline Cortinarius decipiens & 3 & 0.3 & 30 \\
\hline Geopora arenosa & 22 & 5.5 & 20 \\
\hline Hebeloma dunense & 14 & 4.2 & 10 \\
\hline Hebeloma mesophaeum & 1708 & 398.0 & 100 \\
\hline Hebeloma sp. 1/Z17 & 114 & 61.8 & 80 \\
\hline Helvella lacunosa & 116 & 118.6 & 100 \\
\hline Helvella leucomelaena* & 1351 & 3858.5 & 100 \\
\hline Hygrophorus hypothejus & 4 & 0.7 & 20 \\
\hline Hygrophorus pustulatus & 127 & 19.8 & 80 \\
\hline Inocybe tjallingiorum & 9 & 1.1 & 10 \\
\hline Rhizopogon roseolus & 3 & 2.5 & 20 \\
\hline Suillus bovinus & 3 & 2.3 & 10 \\
\hline Suillus luteus & 39 & 43.4 & 60 \\
\hline Thelephora caryophyllea & 15 & 4.2 & 10 \\
\hline Thelephora terrestris & 11 & 4.2 & 30 \\
\hline Tricholoma imbricatum & 230 & 705.2 & 60 \\
\hline Tricholoma scalpturatum & 530 & 163.8 & 60 \\
\hline Tricholoma terreum & 17920 & 6953.0 & 100 \\
\hline
\end{tabular}

Explanations: Stand (plot) area: $1000 \mathrm{~m}^{2}$ each, divided into $10 \mathrm{sub}-$ plots; duration of the survey: 3 years (20 observation visits); age of stand: at the end of the survey; AC3y - total abundance (number) of sporocarps in the plot during 3 years; P3y - total sporocarp production ( $\mathrm{g}$ dry weight) in the plot during 3 years; SF - spatial frequency (the percentage of subplots where sporocarps of a species were found); * - data from 2 years

\section{Post-agricultural sites}

Farmland abandonment, resulted by demographic changes (e.g., ageing of rural population, migration of the youth to the towns), and population movements caused by wars and changes in the agricultural policy of the governments, was intensive and well documented process of many parts of the world, especially of Europe. Here, many farmlands were taken out of agricultural production, which is expected to be one of the most striking features of the recent landscape (Faliński, 1998; Stoate et al., 2009). In many areas, the abandonment of traditional agricultural farmlands provides a basis for the re-establishment of natural or semi-natural habitats. However, 
the intensive agricultural activities and the rapid environmental changes may lead to increasing numbers of old fields that show a low recovery of secondary habitats with similar characteristics to the historic vegetation states (Cramer et al., 2008). The immediate afforestation of abandoned agricultural lands as a strongly supported restoration practice, especially in recent years, is getting to be an increasingly important ecological phenomenon (FAO, 2001).

The change or the end of cultivation practices in farmlands followed by afforestation lead to substantial changes in most of the physical, chemical and biological properties (contents of organic matter, nitrogen and other elements, $\mathrm{pH}$, porosity, bulk density, microbial activity and the overall rate of soil processes) of soils. These previous land-use activities may have persistent effects on forest communities and their functioning, manifesting in a long-term, 80100 years long or even longer recovery of forest soils (van der Wal et al., 2006; Olszewska \& Smal, 2008; Smal \& Olszewska, 2008; von Oheimb et al., 2008).

Agricultural management can reduce the abundance and diversity of soil microfungi and arbuscular mycorrhizae, and affect the rate of recovery of a post-disturbed plant community (van der Heijden et al., 1998; Hedlund, 2002). Moreover, serious difficulties in establishment of trees and ecosystem functioning in old fields have been reported (Dominik, 1961; Szujecki, 1990). In old fields, the rates of natural succession and the recovery of a late successional, well-structured, mature woody vegetation with a stable composition of forest-dwelling species vary considerably: up to 140 years in European mesophilous pine forests and 350 years in European mixed hardwood forests (Faliński, 1986). In the Alps, 100 years after pasture abandonment, some areas were still in an early stage of transition from grassland to a savannah-like forest community with an open canopy (Wiemken \& Boller, 2006), which delayed succession was ascribed to the limitations of ectomycorrhiza formation.

Boerner et al. (1996) showed that ECM inoculua in an active agricultural field were sparse, patchily distributed and surrounded by large areas with a lack of infectivity. This observation was related strongly to the ploughing pattern of the area, where there was a little chance of any seeds of ECM-forming plants to find fungal partners and effectively colonize the site. However, both the infectiveness (calculated based on the number of bioassay seedlings colonized, and the number of ECM tips per a seedling) and richness (the number of ECM types, and the number of rare ECM types) of ECM community increased significantly with time after disturbance, especially in the first 5-10 years. The pre-disturbance level of ECM fungal inocula re-established 25-30 years after agriculture cessation. During these years, increasing number of discrete patches with a high potential of infectiveness were recorded, suggesting a major role of animal faces in ECM dispersal in old fields.

In deforested sites, which were used for agricultural purposes for 30 years and then abandoned for 15 years, a diverse community of ECM propagule bank was found with a high proportion of species of significant host preferences. But this community was different from the one revealed in the reference forest site. The former was less rich in species and showed a strong dominance of Wilcoxina micolae. In the deforested site, the ECM colonization rate on the roots of seedlings was relatively high, but, on some hosts, still lower compared to that of the reference site (Ding et al., 2011).

A high ECM inoculum potential of post-agricultural soils after 10 years of abandonment was shown in a mycorrhization experiment carried out by Menkis et al. (2007). Pine and spruce seedlings, pre-inoculated with Cenococcum geophilum, Piceirhiza bicolorata and Hebeloma crustuliniforme, showed a fast and effective colonization of a diverse ECM community (19 morphotypes, including inoculated species, Rhizopogon sp., Suillus luteus, Suillus sp., Thelephora terrestris, Paxillus sp., Amphinema byssoides and numerous unidentified taxa) over two growing seasons, showing a low impact of inoculation on subsequent fungal community development in this type of habitats. The persistence of the T. terrestris isolate, inoculated on the roots of pine seedlings, and its beneficial effects on the mycorrhizal abundance (counted based on the number of mycorrhizal tips) after two years of outplantation was also confirmed (Hilszczańska \& Sierota, 2006). Other morphotypes found on these seedlings were Amanita sp., Hebeloma sp., Suillus sp., Thelephora terrestris (an indigenous strain) and other unidentified species. After 6-8 years, 17 morphotypes with different proportions were found on the roots of saplings (including the pre-inoculated species) indicating the importance of environmental conditions for the persistent establishment of ECM fungi (Hilszczańska et al., 2011).

Besides the time elapsed after disturbance and the above-ground dispersal vectors, the distance from established vegetation has proved to be a key element for ECM inoculum occurrence and vitality in post-agricultural systems. Mycorrhizal inocula were shown to have low levels on seedlings growing far from mature trees (the abundance of mycorrhizae declined sharply within the circle of $15 \mathrm{~m}$ radius from the base of trees), along with, the mycorrhization level, foliar $\mathrm{N}$ concentrations, and survival of seedlings was higher near established trees (Dickie et al., 2002; Dickie \& Reich, 2005; Dickie et al., 2007). The ECM species richness and community composition were also affected: the species richness declined with distance from trees with a higher number of infrequent spe- 
cies close to the trees. Ascomycetes were relatively more represented at greater distances (Dickie \& Reich, 2005). On the one hand, the facilitation of tree seedlings may be more efficient if seedlings grow near the forest edges and are incorporated into the local common mycorrhizal network (Thiet \& Boerner, 2007). On the other, the close vicinity of abandoned fields to well-established woodlands may contribute to a fast restoration of ECM spore bank (such as in the case of plant seeds, compare Symonides, 1986; Faliński et al., 1998). The close locality of the sites to an established forest, or a single tree, or a group of trees, is among the most important factors affecting the successional trajectories of meadow-type vegetations (Falińska, 2003; Gömöryová et al., 2009).

In post-agricultural systems, a successful tree establishment may be hampered not only by the lack of ECM inocula, but the competition with herbs, which can limit seedlings regardless their distance from mature trees (Dickie et al., 2007). The same effect can be caused by a management practice of sowing additional herbs onto the sites: in which cases, ECM colonization and the survival of tree seedlings were higher in areas where only naturally colonized herbs occurred (Hedlund \& Gormsen, 2002). The composition and structure of vegetation developing in old fields soon after cultivation cessation may vary considerably depending on the type and magnitude of disturbance, crop plant species identity, the time of management discontinuation (spring vs. autumn) and the status of the abandoned field (was it a ploughland, a fallow, or a stubble), soil features, microrelief, the distance from the seed source of native habitats, the animal activity (their rooting, digging, feeding behavior, etc.) and the appearance of mosses and lichens (Faliński, 1998; van der Putten et al., 2000; Cramer et al., 2008; Tokuoka et al., 2011). All these factors may form strong filters for ECM trees or instead, open "the windows of opportunity" for their establishment.

Early successional post-agricultural areas proved to be good model systems for the studies of ECM fungal chronosequences. A series of investigations in the 1980's were carried out in first generation forests planted in old fields; that underpinned the concept of "early-" and "late-stage" fungi. Based on the observations of spatial and temporal occurrence of ECM sporocarps, it was assumed that fungi never form a random pattern. Under recently outplanted saplings of Betula pendula and B. pubescens, Hebeloma crustuliniforme, followed by a Laccaria sp., occurred as a first colonizer. These fungi were joined soon by Thelephora terrestris, Inocybe lanuginella and Lactarius pubescens, other species of Hebeloma, and later by Amanita, Cortinarius and Leccinum. Ten years after outplanting of the birch seedlings, sporocarps of Russula appeared. Sporocarps tended to occur in zones of progressively increasing radius, and the new species occurred usually closer to the stem base, associated to the older roots, representing successional changes in ECM community composition related to tree age (Mason et al., 1982; Last et al., 1983). Similar patterns were observed concerning other tree species, e.g., Pseudotsuga menziesii (Chu-Chou \& Grace, 1981), and Pinus radiata (Chu-Chou, 1979; Chu-Chou \& Grace, 1988), and in another study on birch trees, based on ECM morphotypes (Deacon et al., 1983).

Temporal and spatial sequential appearances of ECM fungi were observed in the natural processes of post-agricultural land reforestations during the study in the complete series of seral communities representing spontaneous vegetation change from a psammophilous grassland to a mesophilous pine forest, which is located in the unique complex of old fields of different age near the edge of the Białowieża old-growth forest (Poland) (Kałucka, 2009). In the plots representing 7 distinctive phases of forest return $\left(13,000 \mathrm{~m}^{2}\right.$ in total, stands up to 100 years old), sporophores of $98 \mathrm{ECM}$ fungal species were recorded in the whole chronosequence; based on sporocarps, after 8-15 years of field abandonment, 44 species were found growing under 6-8 years old pine trees. Strong relationships among the patterns of ECM species composition, frequency and abundance, and forest development, the age of trees, stand structure and soil profile formation suggested that ECM fungal succession is best explained by the development of the vegetation and the habitat. In this successional trajectory of ECM fungi, three successional stages were distinguished:

- Colonization stage - rapid colonization by a rich ECM community, corresponding in some aspects to the "initial floristic composition" model (Egler, 1954), dominated by Inocybe lacera, Laccaria proxima, Suillus luteus, Cortinarius cf. cinnamomeoluteus, Amanita muscaria and Hygrophorus hypothejus, and characterized by a fast increase in species richness, diversity (H-index), sporocarp abundance, and biomass production; it begins with the arrival of the first tree seedlings and ends in open psammophilous grasslands with junipers and scattered pines up to 12 (16) years old (pine cover less than $50 \%)$;

- Stabilization stage - characterized by the increasing abundances of above-mentioned fungal species (except for I. lacera), and with the distinctive occurrence of Chalciporus piperatus, Lactarius rufus, many small-sized Cortinarius, and Tricholoma species; with further increase in species richness and diversity, the sporocarp production reaches its maximum; it begins when pine cover reaches ca $50 \%$, and continues when patches of juniper shrubs and pines increase in their relative cover at the expense of intermixing psammophilous grasslands with a rich moss and lichen layer, until the 
canopy becomes closed when pines are 18 (25) years old; at the end of the period of canopy closure with an intensified litter accumulation, root overgrowth and more xeric soil conditions, the total number of ECM sporocarps decreases and Tricholoma spp. become prevalent in sporocarp biomass production;

- Replacement stage - highlighted by a gradual change in ECM species composition, a partial replacement of species selective for the pre-forest, semi-open habitats; numerous forest-dwelling species, mainly members of genera Russula, Lactarius, Cortinarius and Amanita arrive; fungal species diversity further increases, despite decrease in species richness, conspicuous decrease in the overall carpophore abundance and biomass; Russula spp. become predominant in sporocarp biomass production; it begins when pines are ca 30 years old, with the formation of a multilayered stand structure, the development of soil profile and humus layer; distinct qualitative changes are seen in this stage; 30 ECM species were recorded in the 100 years old stands out of which only one third of taxa were present regularly in earlier (pre-forest) stages.

In undisturbed mature and old-growth forests, ECM fungal species composition is in a relatively stable state, and formed generally by typical forest-dwelling species.

In post-agricultural fields, which were subjected to afforestation by setting naturally mycorrhized, nursery-grown tree seedlings, the successional trajectory of the ECM fungal community can be significantly accelerated, as it was shown in the author's (ILK) unpublished study carried out in a chronosequence of 1-42 years old Scots pine stands in Poland. In a pine stand of $1000 \mathrm{~m}^{2}$ set in an arable field immediately a year after crop cultivation by using one yearold, nursery-grown seedlings, the first ECM fungal sporocarps appeared three years after outplantation. Here, Hebeloma cavipes, Laccaria proxima, Inocybe lacera, and Suillus luteus were recorded. For the fourth year, additional taxa emerged, such as Hebeloma mesophaeum, Thelephora terrestris and Tomentella sp. (Table 2). Within the whole chronosequence of stands examined, the general pattern of the continuous increase in ECM fungal species richness and diversity was observed, while sporocarp number and biomass production were peaked short before the canopy closure (in a 7-year-old stand). The period of highest sporocarp production coincided with an intensive development of fine root biomass (Jagodziński \& Kałucka, 2011). On former agricultural fields, similar pattern of ECM community development was found in the chronosequence of Norway spruce plantations (Gáper \& Lizoň, 1995; Mihál, 1999).
Table 2. The occurrence of ectomycorrhizal fungal sporocarps in three Scots pine plantations of different ages on a post-agricultural land (Bełchatów Industrial Region, Poland)

\begin{tabular}{|c|c|c|c|}
\hline Species & AC3y & P3y & SF \\
\hline \multicolumn{4}{|l|}{ A. 4-year-old stand (P04) } \\
\hline Hebeloma mesophaeum & 2 & 0.5 & 10 \\
\hline Hebeloma cavipes & 467 & 200.3 & 100 \\
\hline Inocybe lacera & 71 & 13.0 & 50 \\
\hline Laccaria proxima & 1935 & 408.3 & 100 \\
\hline Suillus luteus & 36 & 41.9 & 90 \\
\hline Thelephora terrestris & 1 & 0.7 & 10 \\
\hline Tomentella sp. 1/P04 & 94 & n.d. & 70 \\
\hline \multicolumn{4}{|l|}{ B. 7-year-old stand (P07) } \\
\hline Amanita muscaria & 236 & 629.9 & 90 \\
\hline Chalciporus piperatus & 4 & 0.4 & 20 \\
\hline Hebeloma cavipes & 39 & 16.7 & 50 \\
\hline Hygrophorus hypothejus & 152 & 27.4 & 70 \\
\hline Inocybe jacobi & 86 & 0.7 & 60 \\
\hline Inocybe lacera & 61 & 11.2 & 30 \\
\hline Inocybe subcarpta & 81 & 18.5 & 60 \\
\hline Laccaria proxima & 1239 & 261.4 & 100 \\
\hline Lactarius rufus & 18 & 8.7 & 20 \\
\hline Paxillus involutus & 14 & 24.4 & 10 \\
\hline Rhizopogon sp. & 1 & 0.5 & 10 \\
\hline Suillus bovinus & 11 & 22.9 & 10 \\
\hline Suillus luteus & 2687 & 3130.4 & 100 \\
\hline Thelephora terrestris & 4012 & 1154.0 & 100 \\
\hline Tomentella sp. 1/P07 & 1 & n.d. & 10 \\
\hline Tricholoma albobrunneum & 218 & 178.8 & 70 \\
\hline \multicolumn{4}{|l|}{ C. 13-year-old stand (P13) } \\
\hline Amanita muscaria & 46 & 122.8 & 30 \\
\hline Cortinarius sp. 1/P13 & 743 & 83.2 & 60 \\
\hline Hebeloma mesophaeum & 3848 & 896.6 & 90 \\
\hline Hebeloma spp. & 490 & 214.1 & 70 \\
\hline Laccaria laccata & 4 & 0.2 & 10 \\
\hline Laccaria proxima & 1 & 0.2 & 10 \\
\hline Lactarius glyciosmus & 10 & 1.1 & 20 \\
\hline Paxillus involutus & 60 & 104.8 & 70 \\
\hline Russula fragilis & 3 & 0.9 & 30 \\
\hline Suillus luteus & 6 & 7.0 & 10 \\
\hline Thelephora caryophyllea & 41 & 8.4 & 10 \\
\hline Thelephora terrestris & 38 & 23.2 & 50 \\
\hline Tomentella sp. 1/P13 & 15 & n.d. & 40 \\
\hline Tricholoma albobrunneum & 637 & 1953.0 & 100 \\
\hline Tricholoma terreum & 454 & 127.12 & 40 \\
\hline
\end{tabular}

Explanations: Stand (plot) area: $1000 \mathrm{~m}^{2}$ each, divided into 10 subplots; duration of the survey: 3 years (20 observation visits); age of stand: at the end of the survey; AC3y - total abundance (number) of sporocarps in the plot during 3 years; P3y - total sporocarp production (g dry weight) in the plot during 3 years; SF - spatial frequency (the percentage of subplots where sporocarps of a species were found); n.d. - production not estimated (no data) 
The ECM successional trajectories in spontaneous reforestation systems and in tree plantations in post-agricultural lands seemed to be similar; but in the plantations, canopy closure happens usually earlier and at a younger age of trees. In comparable chronosequences of pine stands growing on post-arable sites, the characteristic stage with the dominance of Tricholoma spp. in sporocarp production, associated to recent canopy closure, was observed under 15-20 years old trees in a spontaneously emerged system (Kałucka, 2009), but in the planted pine stand, trees were only 11-13 years old at this successional stage (Table 2). Instead, before canopy closure, ECM species richness increased much faster and was considerably higher in a natural successional trajectory compared to plantations. Therefore, the factors driving the ECM community must include the aboveand below-ground structure of the stand, and both the development of vegetations and habitats, not only the species identity and age of trees.

It is well documented that during forest regeneration after agricultural abandonment, the available $\mathrm{N}$ pools decline due to the substantial transfer of mineralized N from soil into plants (Richter et al., 2000). Also, the foliar $\% \mathrm{~N}$ and the total foliar $\mathrm{N}$ content of overstory vegetation decrease over time, indicating a tightening of $\mathrm{N}$ availability over succession (Compton et al., 2007). There is a strong evidence of an increasing participation of ECM fungi in the process of $\mathrm{N}$ transfer from soil into the trees via the mineralization-mycorrhizal-plant uptake pathway during forest regeneration in old-fields. With time, as stands aged, foliar $\delta^{15} \mathrm{~N}$ decreased and became more negative (Compton et al., 2007). This phenomenon is indicative for the $\mathrm{N}$ resource fractionation of ECM fungi (Högberg, 1997; Hobbie et al., 2005) and after disturbance, for their pivotal role in forest ecosystem recoveries at a time scale of a century.

\section{Conclusion}

Succession is one of the most important ecological processes forming the biosphere. Pioneer or disturbed ecosystems, if not permanently restricted by climatic or edaphic conditions, or if released from disturbance, follow various trajectories of successional processes towards more mature systems. ECM fungi, as obligatory symbionts of the whole range of trees and shrub species, especially in the temperate and boreal zones, are a key organism group that enhance the development of forest communities interacting with vegetation succession and changing soil environment, and subjected to their own successional dynamics. As it was shown in this review, the successful reforestation of disturbed areas, both in primary and secondary successional sites, become possible if only the pre-requisites of ECM fungal propagules are fulfilled via airborne spores from local or remote sources, or spores supplied by animals, spore banks, or via mycelial inocula survived the disturbance, or from functioning ECM networks that can be joined by arriving tree seedlings. ECM inocula may be supplied directly onto the roots of tree seedlings prior to outplanting via a natural infection in the nursery, or throughout an artificial mycorrhization. However, in most cases, the latter one is unnecessary, or unprofitable, or economically unjustified. In early successional sites, ECM fungal inocula and developing ECM communities can speed up or alter the course of forest restoration. Thus, the role of fungi should be considered in afforestation polices aiming land reclamation (Rincón et al., 2006; Menkis et al., 2007) and carbon sequestration (Kałucka \& Jagodziński, 2013). Mechanisms of ECM fungal succession and its interactions with vegetation and habitat development impact ecosystem trajectories after changes in land management practices. This has important implications for biodiversity and sustainability of rare and threatened ecosystems (Thiet \& Boerner, 2007; Gömöryová et al., 2009; Dickie et al., 2011). The role of ECM fungi should be more considered in conservation polices.

\section{Acknowledgements}

This review was supported by the Ministry of Science and Higher Education, Warsaw, Poland (grant nos. 3 P04G 03123 and N N305 2996 40), by the General Directorate of State Forests, Warsaw, Poland (research project 'Environmental and genetic factors affecting productivity of forest ecosystems on forest and post-industrial habitats') and by the Institute of Dendrology, Polish Academy of Sciences, Kórnik, Poland. We would like to thank Dr. Douglas Zook (Global Ecology Education Initiative (GEEI), Boston University) and anonymous reviewer for a significant linguistic improvement of the manuscript.

\section{References}

Adriaensen K, Vrålstad T, Noben JP, Vangronsveld J \& Colpaert JV (2005) Copper-adapted Suillus luteus, a symbiotic solution for pines colonizing $\mathrm{Cu}$ mine spoils. Applied and Environmental Microbiology 71: 7279-7284. doi: 10.1128/aem.71.11.72797284.2005.

Allen MF (1991) The ecology of mycorrhizae. Cambridge University Press, Cambridge, UK.

Bauman JM, Keiffer CH, Hiremath S \& McCarthy BC (2013) Soil preparation methods promoting ectomycorrhizal colonization and American chestnut Castanea dentata establishment in coal mine resto- 
ration. Journal of Applied Ecology 50: 721-729. doi: 10.1111/1365-2664.12070.

Boerner REJ, DeMars BG \& Leicht PN (1996) Spatial patterns of mycorrhizal infectiveness of soils long a successional chronosequence. Mycorrhiza 6: 79-90. doi: 10.1007/s005720050111.

Bois G, Piché Y, Fung MYP \& Khasa DP (2005) Mycorrhizal inoculum potentials of pure reclamation materials and revegetated tailing sands from the Canadian oil sand industry. Mycorrhiza 15: 149-158. doi: 10.1007/s00572-004-0315-4.

Bradshaw AD \& Johnson M (1992) Revegetation of metalliferous mine waste: the range of practical techniques used in Western Europe. Elsevier, Manchester.

Chu-Chou M (1979) Mycorrhizal fungi of Pinus radiata in New Zealand. Soil Biology and Biochemistry 11: 557-562. doi: 10.1016/00380717(79)90021-x.

Chu-Chou M \& Grace LJ (1981) Mycorrhizal fungi of Pseudotsuga menziesii in the north island of New Zealand. Soil Biology and Biochemistry 13: 247-249.

Chu-Chou M \& Grace LJ (1988) Mycorrhizal fungi of radiata pine in different forests of the north and south islands in New Zealand. Soil Biology and Biochemistry 20: 883-886. doi: 10.1016/00380717(88)90098-3.

Colpaert JV, Wevers JHL, Krznaric E \& Adriaensen K (2011) How metal-tolerant ecotypes of ectomycorrhizal fungi protect plants from heavy metal pollution. Annals of Forest Science 68: 17-24. doi: 10.1007/s13595-010-0003-9.

Compton JE, Hooker TD \& Perakis SS (2007) Ecosystem $\mathrm{N}$ distribution and $\delta^{15} \mathrm{~N}$ during a century of forest regrowth after agricultural abandonment. Ecosystems 10: 1197-1208. doi: 10.1007/ s10021-007-9087-y.

Conesa HM \& Schulin R (2010) The Cartagena - La Union mining district (SE Spain): a review of environmental problems and emerging phytoremediation solutions after fifteen years research. Journal of Environmental Monitoring 12: 1225-1233. doi: 10.1039/c000346h.

Cramer VA, Hobbs RJ \& Standish RJ (2008) What's new about old fields? Land abandonment and ecosystem assembly. Trends in Ecology \& Evolution 23: 104-112. doi: 10.1016/j.tree.2007.10.005.

Danielson RM (1991) Temporal changes and effects of amendments on the occurrence of sheathing (ecto-) mycorrhizas of conifers growing in oil sands tailings and coal spoil. Agriculture, Ecosystems \& Environment 35: 261-281. doi: 10.1016/0167-8809(91)90054-2.

Danielson RM \& Visser S (1989) Host response to inoculation and behaviour of introduced and indigenous ectomycorrhizal fungi of jack pine grown on oil-sands tailings. Canadian Journal of Forest Research 19: 1412-1421. doi: 10.1139/x89-216.

Danielson RM, Visser S \& Parkinson D (1983) Microbial activity and mycorrhizal potential of four overburden types used in the reclamation of extracted oil sands. Canadian Journal of Soil Science 63: 363-375.

Deacon JW, Donaldson SJ \& Last FT (1983) Sequences and interactions of mycorrhizal fungi on birch. Plant and Soil 71: 257-262. doi: 10.1007/ bf02182660.

Dickie IA, Koide RT \& Steiner KC (2002) Influences of established trees on mycorrhizas, nutrition, and growth of Quercus rubra seedlings. Ecological Monographs 72: 505-521. doi: 10.1890/0012-9615(2002)072 [0505:IOETO$\mathrm{M}] 2.0 . \mathrm{CO} ; 2$.

Dickie IA, Martinez-Garcia LB, Koele N, Grelet GA, Tylianakis JM, Peltzer DA \& Richardson SJ (2013) Mycorrhizas and mycorrhizal fungal communities throughout ecosystem development. Plant and Soil 367: 11-39. doi: 10.1007/s11104-013-1609-0.

Dickie IA \& Reich PB (2005) Ectomycorrhizal fungal communities at forest edges. Journal of Ecology 93: 244-255. doi: 10.1111/j.13652745.2005.00977.x.

Dickie IA, Schnitzer SA, Reich PB \& Hobbie SE (2007) Is oak establishment in old-fields and savanna openings context dependent? Journal of Ecology 95: 309-320. doi: 10.1111/j.13652745.2006.01202.x.

Dickie IA, Yeates GW, St John MG, Stevenson BA, Scott JT, Rillig MC, Peltzer DA, Orwin KH, Kirschbaum MUF, Hunt JE, Burrows LE, Barbour MM \& Aislabie J (2011) Ecosystem service and biodiversity trade-offs in two woody successions. Journal of Applied Ecology 48: 926-934. doi: 10.1111/j.1365-2664.2011.01980.x.

Ding Q, Liang Y, Legendre P, He X-h, Pei K-q, Du X-j \& Ma K-p (2011) Diversity and composition of ectomycorrhizal community on seedling roots: the role of host preference and soil origin. Mycorrhiza 21: 669-680. doi: 10.1007/s00572-011-0374-2.

Dominik T (1961) Badania nad przeszczepianiem mikrobiocenoz gleb leśnych na tereny rolne. Prace Instytutu Badawczego Leśnictwa 210: 103-162.

Egler FE (1954) Vegetation science concepts. I. Initial floristic composition - a factor in old-field vegetation development. Vegetatio 4: 412-417.

Falińska K (2003) Alternative pathways of succession: species turnover patterns in meadows abandoned for 30 years. Phytocoenosis 15(N.S.) Archivum Geobotanicum 9: 1-104.

Faliński JB (1986) Vegetation dynamics in temperate lowland primeval forests. Ecological studies in Białowieża Forest. Dr W. Junk Publishers, Dordrecht/Boston/Lancaster. Geobotany 8: 1-537. 
Faliński JB (1998) Dioecious woody pioneer species (Juniperus communis, Populus tremula, Salix sp. div.) in the secondary succession and regeneration: Project Return of Forest 2: long-term studies: 1970-1997. Phytocoenosis 10 (N.S.) Supplementum Cartographiae Geobotanicae 8: 1-156.

Food and Agriculture Organization of the United Nations (2001) Global Forest Resources Assessment 2000 - Main Report. FAO Forestry Paper 140. FAO, Rome.

Gáper J \& Lizoň P (1995) Sporocarp succession of mycorrhizal fungi in the Norway spruce plantations in formerly agricultural land: Structure and function of roots (ed. by F Baluška, M Ciamporova, O Gasparikova \& PW Barlow) Kluver Academic Publishers, Dordrecht, the Netherlands, pp. 349-352.

Gebhardt S, Neubert K, Wöllecke J, Müenzenberger B \& Hüttl RF (2007) Ectomycorrhiza communities of red oak (Quercus rubra L.) of different age in the Lusatian lignite mining district, East Germany. Mycorrhiza 17: 279-290. doi: 10.1007/ s00572-006-0103-4.

Glen M, Bougher NL, Colquhoun IJ, Vlahos S, Loneragan WA, O’Brien PA \& Hardy GESJ (2008) Ectomycorrhizal fungal communities of rehabilitated bauxite mines and adjacent, natural jarrah forest in Western Australia. Forest Ecology and Management 255: 214-225. doi: 10.1016/j.foreco.2007.09.007.

Gömöryová E, Hrivnák R, Janišová M, Ujházy K \& Gömöry D (2009) Changes of the functional diversity of soil microbial community during the colonization of abandoned grassland by a forest. Applied Soil Ecology 43: 191-199. doi: 10.1016/j. apsoil.2009.07.007.

Grossnickle SC (2005) Importance of root growth in overcoming planting stress. New Forests 30: 273-294. doi: 10.1007/s11056-004-8303-2.

Grossnickle SC \& Reid CPP (1982) The use of ectomycorrhizal conifer seedlings in the revegetation of a high-elevation mine site. Canadian Journal of Forest Research 12: 354-361.

Hedlund K (2002) Soil microbial community structure in relation to vegetation management on former agricultural land. Soil Biology and Biochemistry 34: 1299-1307. doi: 10.1016/s00380717(02)00073-1.

Hedlund K \& Gormsen D (2002) Mycorrhizal colonization of plants in set-aside agricultural land. Applied Soil Ecology 19: 71-78. doi: 10.1016/ s0929-1393(01)00174-3.

Helm DJ \& Carling DE (1993) Use of soil transfer for reforestation on abandoned mined lands in Alaska. II. Effects of soil transfers from different successional stages on growth and mycorrhizal formation by Populus balsamifera and Alnus crispa. Mycorrhiza 3: 107-114. doi: 10.1007/ bf00208918.

Hilszczańska D \& Sierota Z (2006) Persistence of ectomycorrhizas by Thelephora terrestris on outplanted Scots pine seedlings. Acta Mycologica 41: $313-318$.

Hilszczańska D, Sierota Z \& Małecka M (2011) Ectomycorrhizal status of Scots pine saplings growing in post-agricultural soils. Polish Journal of Environmental Studies 20: 83-88.

Hobbie EA (2006) Carbon allocation to ectomycorrhizal fungi correlates with belowground allocation in culture studies. Ecology 87: 563-569. doi: 10.1890/05-0755.

Hobbie EA, Jumpponen A \& Trappe J (2005) Foliar and fungal ${ }^{15} \mathrm{~N}:{ }^{14} \mathrm{~N}$ ratios reflect development of mycorrhizae and nitrogen supply during primary succession: testing analytical models. Oecologia 146: 258-268. doi: 10.1007/s00442-005-0208-z.

Högberg P (1997) ${ }^{15} \mathrm{~N}$ natural abundance in soilplant systems. New Phytologist 137: 179-203. doi: 10.1046/j.1469-8137.1997.00808.x.

Hrynkiewicz K, Haug I \& Baum C (2008) Ectomycorrhizal community structure under willows at former ore mining sites. European Journal of Soil Biology 44: 37-44. doi: 10.1016/j.ejsobi.2007.10.004.

Huang J, Nara K, Lian C, Zong K, Peng K, Xue S \& Shen Z (2012) Ectomycorrhizal fungal communities associated with Masson pine (Pinus massoniana Lamb.) in $\mathrm{Pb}-\mathrm{Zn}$ mine sites of central south China. Mycorrhiza 22: 589-602. doi: 10.1007/ s00572-012-0436-0.

Huang J, Nara K, Zong K, Wang J, Xue S, Peng K, Shen Z \& Lian C (2014) Ectomycorrhizal fungal communities associated with Masson pine (Pinus massoniana) and white oak (Quercus fabri) in a manganese mining region in Hunan Province, China. Fungal Ecology 9: 1-10. doi: 10.1016/j. funeco.2014.01.001.

Hüttl RF \& Weber E (2001) Forest ecosystem development in post-mining landscapes: a case study of the Lusatian lignite district. Naturwissenschaften 88: 322-329. doi: 10.1007/s001140100241.

Jagodziński AM \& Kałucka I (2010) Fine roots biomass and morphology in a chronosequence of young Pinus sylvestris stands growing on a reclaimed lignite mine spoil heap. Dendrobiology 64: 19-30.

Jagodziński AM \& Kałucka I (2011) Fine root biomass and morphology in an age-sequence of post-agricultural Pinus sylvestris L. stands. Dendrobiology 66: 71-84.

Jagodziński AM, Kałucka I, Horodecki P \& Oleksyn J (2014) Aboveground biomass allocation and accumulation in a chronosequence of young $\mathrm{Pi}$ nus sylvestris stands growing on a lignite mine 
spoil heap. Dendrobiology 72: 139-150. doi: 10.12657/denbio.072.012.

Jourand P, Ducousso M, Reid R, Majorel C, Richert C, Riss J \& Lebrun M (2010) Nickel-tolerant ectomycorrhizal Pisolithus albus ultramafic ecotype isolated from nickel mines in New Caledonia strongly enhance growth of the host plant Eucalyptus globulus at toxic nickel concentrations. Tree Physiology 30: 1311-1319. doi: 10.1093/treephys/tpq070.

Kałucka I (2009) Macrofungi in the secondary succession on the abandoned farmland near the Bialowieza old-growth forest. Monographiae Botanicae 99: 1-155.

Kałucka I \& Jagodziński AM (2013) Ectomycorrhizal fungi and carbon dynamics in forest ecosystems. Sylwan 157: 817-830.

Klironomos J, Zobel M, Tibbett M, Stock WD, Rillig MC, Parrent JL, Moora M, Koch AM, Facelli JM, Facelli E, Dickie IA \& Bever JD (2011) Forces that structure plant communities: quantifying the importance of the mycorrhizal symbiosis. New Phytologist 189: 366-370. doi: 10.1111/j.14698137.2010.03550.x.

Krpata D, Peintner U, Langer I, Fitz WJ \& Schweiger P (2008) Ectomycorrhizal communities associated with Populus tremula growing on a heavy metal contaminated site. Mycological Research 112: 1069-1079. doi: 10.1016/j.mycres.2008.02.004.

Lambers H, Raven JA, Shaver GR \& Smith SE (2008) Plant nutrient-acquisition strategies change with soil age. Trends in Ecology \& Evolution 23: 95-103. doi: 10.1016/j.tree.2007.10.008.

Last FT, Mason PA, Wilson J \& Deacon JW (1983) Fine roots and sheathing mycorrhizas: their formation, function and dynamics. Plant and Soil 71: 9-21. doi: 10.1007/bf02182637.

Leski T, Pietras M \& Rudawska M (2010) Ectomycorrhizal fungal communities of pedunculate and sessile oak seedlings from bare-root forest nurseries. Mycorrhiza 20: 179-190. doi: 10.1007/ s00572-009-0278-6.

Lunt PH \& Hedger JN (2003) Effects of organic enrichment of mine spoil on growth and nutrient uptake in oak seedlings inoculated with selected ectomycorrhizal fungi. Restoration Ecology 11: 125-130. doi: 10.1046/j.1526-100X.2003.09968.x.

Macdonald SE, Landhäusser SM, Skousen J, Franklin J, Frouz J, Hall S, Jacobs DF \& Quideau S (2015) Forest restoration following surface mining disturbance: challenges and solutions. New Forests 46: 703-732. doi: 10.1007/s11056-015-9506-4.

Malajczuk N, Reddell P \& Brundrett M (1994) Role of ectomycorrhizal fungi in minesite reclamation: Mycorrhizae and plant health (ed. by FL Pfleger \& RG Linderman) The American Phytopathological Society Symposium Series, APS Press, Minnesota, pp. $83-100$.
Marx DH (1975) Mycorrhizae and establishment of trees on strip-mined land. The Ohio Journal of Science 75: 288-297.

Marx DH (1977) Tree host range and world distribution of the ectomycorrhizal fungus Pisolithus tinctorius. Canadian Journal of Microbiology 23: 217-223.

Marx DH, Marrs LF \& Cordell CE (2002) Practical use of the mycorrhizal fungal technology in forestry, reclamation, arboriculture, agriculture, and horticulture. Dendrobiology 47: 27-40.

Mason PA, Last FT, Pelham J \& Ingleby K (1982) Ecology of some fungi associated with an ageing stand of birches (Betula pendula and Betula pubescens). Forest Ecology and Management 4: 19-39. doi: 10.1016/0378-1127(82)90026-3.

Menkis A, Vasiliauskas R, Taylor AFS, Stenlid J \& Finlay R (2007) Afforestation of abandoned farmland with conifer seedlings inoculated with three ectomycorrhizal fungi-impact on plant performance and ectomycorrhizal community. Mycorrhiza 17: 337-348. doi: 10.1007/s00572-007-0110-0.

Mihál I (1999) Production of fruiting bodies of ectomycorrhizal fungi in spruce monocultures planted on former arable land. Ekologia (Bratislava) 18: $125-133$.

Münzenberger B, Golldack J, Ullrich A, Schmincke B \& Hüttl RF (2004) Abundance, diversity, and vitality of mycorrhizae of Scots pine (Pinus sylvestris L.) in lignite recultivation sites. Mycorrhiza 14: 193-202. doi: 10.1007/s00572-003-0257-2.

Olszewska M \& Smal H (2008) The effect of afforestation with Scots pine (Pinus silvestris L.) of sandy post-arable soils on their selected properties. I. Physical and sorptive properties. Plant and Soil 305: 157-169. doi: 10.1007/s11104-008-9537-0.

Onwuchekwa NE, Zwiazek JJ, Quoreshi A \& Khasa DP (2014) Growth of mycorrhizal jack pine (Pinus banksiana) and white spruce (Picea glauca) seedlings planted in oil sands reclaimed areas. Mycorrhiza 24: 431-441. doi: 10.1007/s00572-0140555-x.

Pachlewski R (1956) Badania mikotrofizmu naturalnych zespołów roślinnych na hałdach żużlowo-łupkowych w Wałbrzychu. Roczniki Nauk Leśnych 14: 267-292.

Pachlewski R (1958) Badania mikotrofizmu naturalnych zespołów roślinnych na hałdach górniczych w Knurowie i Gliwicach na Górnym Śląsku. Prace Instytutu Badawczego Leśnictwa 182: 173-209.

Parraga-Aguado I, Querejeta J-I, González-Alcaraz M-N, Jiménez-Cárceles FJ \& Conesa HM (2014) Usefulness of pioneer vegetation for the phytomanagement of metal(loid)s enriched tailings: Grasses vs. shrubs vs. trees. Journal of Environmental Management 133: 51-58. doi: 10.1016/j. jenvman.2013.12.001. 
Pietras M, Rudawska M, Leski T \& Karliński L (2013) Diversity of ectomycorrhizal fungus assemblages on nursery grown European beech seedlings. Annals of Forest Science 70: 115-121. doi: 10.1007/ s13595-012-0243-y.

Read DJ (1991) Mycorrhizas in Ecosystems. Experientia 47: 376-391. doi: 10.1007/bf01972080.

Read DJ \& Perez-Moreno J (2003) Mycorrhizas and nutrient cycling in ecosystems - a journey towards relevance? New Phytologist 157: 475-492. doi: 10.1046/j.1469-8137.2003.00704.x.

Reddell P, Gordon V \& Hopkins MS (1999) Ectomycorrhizas in Eucalyptus tetrodonta and E. miniata forest communities in tropical northern Australia and their role in the rehabilitation of these forests following mining. Australian Journal of Botany 47: 881-907. doi: 10.1071/bt97126.

Richter DD, Markewitz D, Heine PR, Jin V, Raikes J, Tian K \& Wells CG (2000) Legacies of agriculture and forest regrowth in the nitrogen of oldfield soils. Forest Ecology and Management 138: 233-248. doi: 10.1016/s0378-1127(00)00399-6.

Rincón A, de Felipe MR \& Fernández-Pascual M (2007) Inoculation of Pinus halepensis Mill. with selected ectomycorrhizal fungi improves seedling establishment 2 years after planting in a degraded gypsum soil. Mycorrhiza 18: 23-32. doi: 10.1007/s00572-007-0149-y.

Rincón A, Ruíz-Díez B, Fernández-Pascual $M$, Probanza A, Pozuelo JM \& de Felipe MR (2006) Afforestation of degraded soils with Pinus halepensis Mill.: Effects of inoculation with selected microorganisms and soil amendment on plant growth, rhizospheric microbial activity and ectomycorrhizal formation. Applied Soil Ecology 34: 42-51. doi: 10.1016/j.apsoil.2005.12.004.

Russell WB \& La Roi GH (1986) Natural vegetation and ecology of abandoned coal mined land, Rocky Mountain Foothills, Alberta, Canada. Canadian Journal of Botany 64: 1286-1298. doi:10.1139/ b86-177.

Schramm JR (1966) Plant colonization studies on black wastes from anthracite mining in Pennsylvania. Transactions of the American Philosophical Society 56: 5-189.

Simard SW, Beiler KJ, Bingham MA, Deslippe JR, Philip LJ \& Teste FP (2012) Mycorrhizal networks: Mechanisms, ecology and modelling. Fungal Biology Reviews 26: 39-60. doi:10.1016/j. fbr.2012.01.001.

Simard SW, Jones MD \& Durall DM (2002) Carbon and nutrient fluxes within and between mycorrhizal plants: Mycorrhizal Ecology (ed. by MGA van der Heijden \& IR Sanders) Ecological Studies 157: $33-74$.

Smal H \& Olszewska M (2008) The effect of afforestation with Scots pine (Pinus silvestris L.) of sandy post-arable soils on their selected properties. II. Reaction, carbon, nitrogen and phosphorus. Plant and Soil 305: 171-187. doi: 10.1007/s11104008-9538-z.

Smith SE \& Read DJ (2008) Mycorrhizal Symbiosis. $3^{\text {rd }}$ edn. Academic Press.

StanturfJA, Palik BJ \& Dumroese RK (2014) Contemporary forest restoration: A review emphasizing function. Forest Ecology and Management 331: 292-323. doi: 10.1016/j.foreco.2014.07.029.

Staudenrausch S, Kaldorf M, Renker C, Luis P \& Buscot F (2005) Diversity of the ectomycorrhiza community at a uranium mining heap. Biology and Fertility of Soils 41: 439-446. doi: 10.1007/ s00374-005-0849-4.

Stoate C, Báldi A, Beja P, Boatman ND, Herzon I, van Doorn A, de Snoo GR, Rakosy L \& Ramwell C (2009) Ecological impacts of early 21 st century agricultural change in Europe - A review. Journal of Environmental Management 91: 22-46. doi: 10.1016/j.jenvman.2009.07.005.

Symonides E (1986) Seed bank in old-field successional ecosystems. Ekologia Polska - Polish Journal of Ecology 34: 3-29.

Szujecki A (1990) Ekologiczne aspekty odtwarzania ekosystemów leśnych na gruntach porolnych. Sylwan 134: $23-40$.

Thiet RK \& Boerner REJ (2007) Spatial patterns of ectomycorrhizal fungal inoculum in arbuscular mycorrhizal barrens communities: implications for controlling invasion by Pinus virginiana. Mycorrhiza 17: 507-517. doi: 10.1007/s00572-0070123-8.

Tokuoka Y, Ohigashi K \& Nakagoshi N (2011) Limitations on tree seedling establishment across ecotones between abandoned fields and adjacent broad-leaved forests in eastern Japan. Plant Ecology 212: 923-944. doi: 10.1007/s11258-0109868-9.

Trappe JM \& Luoma DL (1992) The Ties That Bind: Fungi in Ecosystems: The Fungal Community. Its Organization and Role in the Ecosystem. $2^{\text {nd }}$ ed. (ed. by GC Carrol \& DT Wicklow) Marcel Dekker, Inc., New York, Basel, Hong Kong, pp. 17-27.

van Breugel M, Ransijn J, Craven D, Bongers F \& Hall JS (2011) Estimating carbon stock in secondary forests: Decisions and uncertainties associated with allometric biomass models. Forest Ecology and Management 262: 1648-1657. doi: 10.1016/j.foreco.2011.07.018.

van der Heijden MGA \& Horton TR (2009) Socialism in soil? The importance of mycorrhizal fungal networks for facilitation in natural ecosystems. Journal of Ecology 97: 1139-1150. doi: 10.1111/j.1365-2745.2009.01570.x.

van der Heijden MGA, Klironomos JN, Ursic M, Moutoglis P, Streitwolf-Engel R, Boller T, Wiemken A 
\& Sanders IR (1998) Mycorrhizal fungal diversity determines plant biodiversity, ecosystem variability and productivity. Nature 396: 69-72.

van der Putten WH, Mortimer SR, Hedlund K, Van Dijk C, Brown VK, Lepä J, Rodriguez-Barrueco C, Roy J, Len TAD, Gormsen D, Korthals GW, Lavorel S, Santa Regina I \& Smilauer P (2000) Plant species diversity as a driver of early succession in abandoned fields: a multi-site approach. Oecologia 124: 91-99. doi: 10.1007/s004420050028.

van der Wal A, van Veen JA, Smant W, Boschker HTS, Bloem J, Kardol P, van der Putten WH \& de Boer W (2006) Fungal biomass development in a chronosequence of land abandonment. Soil Biology and Biochemistry 38: 51-60. doi: 10.1016/j. soilbio.2005.04.017.

Visser S (1995) Ectomycorrhizal fungal succession in jack pine stands following wildfire. New Phy- tologist 129: $389-401$. doi: 10.1111/j.14698137.1995.tb04309.x.

von Oheimb G, Härdtle W, Naumann PS, Westphal C, Assmann T \& Meyer H (2008) Long-term effects of historical heathland farming on soil properties of forest ecosystems. Forest Ecology and Management 255: 1984-1993. doi: 10.1016/j. foreco.2007.12.021.

Wiemken V \& Boller T (2006) Delayed succession from alpine grassland to savannah with upright pine: Limitation by ectomycorrhiza formation? Forest Ecology and Management 237: 492-502. doi: 10.1016/j.foreco.2006.09.084.

Xu D, Dell B, Malajczuk N \& Gong M (2001) Effects of $\mathrm{P}$ fertilisation and ectomycorrhizal fungal inoculation on early growth of eucalypt plantations in southern China. Plant and Soil 233: 47-57. doi: 10.1023/a:1010355620452. 